\title{
The placenta and adverse pregnancy outcomes - opening the black box?
}

\author{
Alexander Heazell \\ From Stillbirth Summit 2014 \\ Medina, MN, USA. 19-21 June 2014
}

A healthy placenta is critical for a healthy pregnancy. Conversely, abnormal placental structure and function is seen in conditions which are associated with stillbirth including: fetal growth restriction, preeclampsia, placental abruption and obstetric cholestasis. Abnormalities can be seen ranging from a reduction in placental size in stillbirth to microscopic changes in placental villous architecture [1]. Placental examination is advocated after stillbirth by respected guidelines [2-4]; this recommendation is based upon the frequency of abnormalities seen in placentas after stillbirth $[5,6]$, the reduction in unexplained stillbirths when placental histological examination is performed and the cost-effectiveness per abnormality detected $[1,7]$.

The placenta has previously been referred to as a "diary of pregnancy" and it is tempting to compare examination of the placenta after stillbirth with the "black-box" flight data recorder used after aircraft accidents. To be certain that placental findings are significant in a case of stillbirth they should reflect (relevant) changes that occurred prior to fetal death. Thus, there should be no artefact from inutero retention or storage. Placental findings should give information regarding conditions present and be specific for adverse pregnancy outcome (i.e. not occur in healthy pregnancy). Ultimately, the information obtained must be useful, aiding understanding of death by clinicians and inform future care.

Storage and fixation of placental tissue can alter findings on examination. Naeye et al. states that "troublesome artefacts" can appear after 48 hours of refrigeration [8]. This is supported by qualitative and quantitative assessment Garrod et al. demonstrated changes in villous vascularity after 48 hours refrigeration [9]. Thus, every effort should be made to minimise the

Correspondence: alexander.heazell@manchester.ac.uk

Maternal and Fetal Health Research Centre, Manchester Academic Health Science Centre, University of Manchester, UK time of storage prior to examination. The effects of retention in utero before birth are more difficult to assess as the time of fetal death is usually unknown. Genest estimated that in utero retention was associated with villous degeneration, particularly of fetal blood vessels and villous stroma [10].

A systematic review of histopathological assessment of the placenta found that a placental cause is reported in $11.2-64.9 \%$ and associated with stillbirth in $31.5 \%$ $84 \%$ of cases [11]. The greatest influence on the proportion of stillbirths classified as having "placental" abnormalities was the classification system employed. The specificity of placental abnormalities for stillbirth has previously been questioned by the high incidence of histological lesions in apparently normal pregnancies and the large variation in agreement between pathologists when identifying lesions (Kappa - 0.25-0.91) $[12,13]$. These data highlight the importance of international consensus in the definition of placental lesions to improve study quality. Accurate description of lesions will also enable better understanding of their origins. One example of this is syncytial knots (also known as syncytial nuclear aggregates). The formation of syncytial knots are increased in hypoxia and oxidative stress in vitro [14], which supports the reported association between syncytial knots/nuclear aggregates and maternal vascular malperfusion $[13,15]$.

Furthermore, evaluation of placental structure and function can be used to explore clinical scenarios relating to stillbirth such as maternal perception of reduced fetal movements, advanced maternal age and fetal growth restriction [16-18]. These clinical conditions are all associated with alterations in placental structure, specifically increased syncytial knots/nuclear aggregates, changes in trophoblast proliferation and alterations in amino-acid transport [14,19-21]. Importantly, these observations provide plausible biological association 
between these clinical scenarios and stillbirth from placental causes. These suggest that better appreciation of placental function in utero may provide an opportunity to identify pregnancies at risk of stillbirth to target intervention [22,23].

Published: 15 April 2015

\section{References}

1. Heazell $A E$, Martindale EA: Can post-mortem examination of the placenta help determine the cause of stillbirth? Journal of Obstetrics and Gynaecology 2009, 29(3):225-228.

2. American College of Obstetricians and Gynecologists: ACOG Practice Bulletin No. 102: management of stillbirth. Obstet Gynecol 2009, 113(3):748-761

3. Royal College of Obstetricians and Gynaecologists: Green-Top Guideline 55 - Late Intrauterine Fetal Death and Stillbirth. London: Royal College of Obstetricians and Gynaecologists; 2010.

4. Flenady V, King J, Charles A, Gardener G, Ellwood D, Day K, McCowan L, Kent A, Tudehope D, Richardson R, et al: PSANZ Clinical Practice Guideline for Perinatal Mortality Version 2.2. 2009.

5. Korteweg FJ, Erwich JJ, Timmer A, van der Meer J, Ravise JM, Veeger NJ, Holm JP: Evaluation of 1025 fetal deaths: proposed diagnostic workup. Am J Obstet Gynecol 2012, 206(1):53 e51-53 e12.

6. Pinar H, Goldenberg RL, Koch MA, Heim-Hall J, Hawkins HK, Shehata B, Abramowsky C, Parker CB, Dudley DJ, Silver RM, et al: Placental findings in singleton stillbirths. Obstet Gynecol 2014, 123(2 Pt 1):325-336.

7. Heazell $A E$, Byrd LM, Cockerill $R$, Whitworth MK: Investigations following stillbirth - which tests are most valuable? Arch Dis Child 2011, 96(Suppl 1):Fa135.

8. Naeye RL: Functionally important disorders of the placenta, umbilical cord, and fetal membranes. Hum Pathol 1987, 18(7):680-691.

9. Garrod A, Batra G, Ptacek I, Heazell AE: Duration and method of tissue storage alters placental morphology - implications for clinical and research practice. Placenta 2013, 34(11):1116-1119.

10. Genest DR: Estimating the time of death in stillborn fetuses: II. Histologic evaluation of the placenta; a study of 71 stillborns. Obstet Gynecol 1992, 80(4):585-592.

11. Ptacek I, Sebire NJ, Man JA, Brownbill P, Heazell AE: Systematic review of placental pathology reported in association with stillbirth. Placenta 2014, 35(8):552-562

12. Pathak S, Lees CC, Hackett G, Jessop F, Sebire NJ: Frequency and clinical significance of placental histological lesions in an unselected population at or near term. Virchows Arch 2011, 459(6):565-572

13. Turowski G, Berge LN, Helgadottir LB, Jacobsen EM, Roald B: A new, clinically oriented, unifying and simple placental classification system. Placenta 2012, 33(12):1026-1035.

14. Heazell AE, Moll SJ, Jones CJ, Baker PN, Crocker IP: Formation of syncytial knots is increased by hyperoxia, hypoxia and reactive oxygen species. Placenta 2007, 28(Supplement 1):S33-S40.

15. Pinar $\mathrm{H}$, Carpenter $\mathrm{M}$ : Placenta and umbilical cord abnormalities seen with stillbirth. Clin Obstet Gynecol 2010, 53(3):656-672.

16. Froen JF, Arnestad M, Frey K, Vege A, Saugstad OD, Stray-Pedersen B: Risk factors for sudden intrauterine unexplained death: epidemiologic characteristics of singleton cases in Oslo, Norway, 1986-1995. Am J Obstet Gynecol 2001, 184(4):694-702

17. Rasmussen S, Albrechtsen S, Irgens LM, Dalaker K, Maartmann-Moe H, Vlatkovic L, Markestad T: Risk factors for unexplained antepartum fetal death in Norway 1967-1998. Early Hum Dev 2003, 71(1):39-52.

18. Gardosi J, Kady SM, McGeown P, Francis A, Tonks A: Classification of stillbirth by relevant condition at death (ReCoDe): population based cohort study. British Medical Journal 2005, 331(7525):1113-1117.

19. Warrander LK, Batra G, Bernatavicius G, Greenwood SL, Dutton P, Jones RL, Sibley CP, Heazell AE: Maternal perception of reduced fetal movements is associated with altered placental structure and function. PLOS One 2012, 7(4):e34851.

20. Glazier JD, Cetin I, Perugino G, Ronzoni S, Grey AM, Mahendran D, Marconi AM, Pardi G, Sibley CP: Association between the activity of the system A amino acid transporter in the microvillous plasma membrane of the human placenta and severity of fetal compromise in intrauterine growth restriction. Pediatr Res 1997, 42(4):514-519.

21. Heazell $A E$, Sharp AN, Baker PN, Crocker IP: Intra-uterine growth restriction is associated with increased apoptosis and altered expression of proteins in the p53 pathway in villous trophoblast. Apoptosis 2011, 16:135-144.

22. Benton SJ, Hu Y, Xie F, Kupfer K, Lee SW, Magee LA, von Dadelszen P: Can placental growth factor in maternal circulation identify fetuses with placental intrauterine growth restriction? Am J Obstet Gynecol 2011.

23. Heazell AE, Bernatavicius G, Roberts SA, Garrod A, Whitworth MK, Johnstone ED, Gillham JC, Lavender T: A randomised controlled trial comparing standard or intensive management of reduced fetal movements after 36 weeks gestation-a feasibility study. BMC Pregnancy Childbirth 2013, 13:95.

doi:10.1186/1471-2393-15-S1-A5

Cite this article as: Heazell: The placenta and adverse pregnancy outcomes - opening the black box? BMC Pregnancy and Childbirth 2015 15(Suppl 1):A5

\section{Submit your next manuscript to BioMed Central and take full advantage of:}

- Convenient online submission

- Thorough peer review

- No space constraints or color figure charges

- Immediate publication on acceptance

- Inclusion in PubMed, CAS, Scopus and Google Scholar

- Research which is freely available for redistribution
C Biomed Central 